\title{
The Vascular Branches of Stigmarian Rootlets.
}

\author{
BY \\ F. E. WEISS, D.Sc., F.L.S., \\ Professor of Botany in Owens College, Manchester. \\ With Plate XXVI.
}

T $\mathrm{N}$ his 'Cours de botanique fossile 1,' and also in his 'Etude sur les Stigmaria ${ }^{2}$ ' in the Annales des Sciences géologiques, Renault has described and figured rootlets of Stigmaria from the neighbourhood of Manchester, in which a very delicate vascular branch was given off from the stele. Such branches were given off according to Renault from each of the three protoxylem-groups of what he considered the triarch rootlet of Stigmaria and went to supply lateral rootlets (radicelles). The importance of this observation will be recognized by the following conclusion which Renault drew from it : 'Ce caractère important éloigne toute idée de rapprochement entre les organes qui nous occupent maintenant et les racines des plantes cryptogames.'

Williamson ('87) in his criticism of this statement ${ }^{3}$ points out that the rootlets of Stigmaria branch invariably by dichotomy, and states that he has seen nothing like the branching figured by Renault in any of the innumerable rootlets in his cabinet.

1 Renault, B., Cours de botanique fossile, Pl, XX, Fig. 4.

2 Renault, B., Annales des sciences géologiques, I882, Pl. II, Fig. 8.

3 Williamson, W. C. ('87), p. 32, note $\mathbf{I}$.

[Annals of Botany, Vo1. XVI. No. LXIII. September, 1902.] 
Solms-Laubach ('91) in his description of the rootlets of Stigmaria, in which he reproduces Renault's figure ${ }^{1}$, expresses some doubt as to the existence of such tracheal branches from the central cylinder of the rootlets, and does not support Renault's view as to their mode of branching.

In a previous publication (Weiss, 1902) I have pointed out that the vascular branches described by Renault do actually occur in Stigmarian rootlets, and have figured such a branch in a rootlet ${ }^{2}$, which was characterized by its well-preserved middle cortex. I was unable in the case of that specimen to do more than confirm Renault's observation, which up to that time had not met with confirmation. On the publication of my paper, Dr. D. H. Scott kindly sent me some notes which he had made on Stigmarian rootlets in preparation for his 'Studies in Fossil Botany.' From these it appears that Dr. Scott had no doubt as to the correctness of Renault's observation, as he himself had repeatedly come across such delicate vascular branches, and had 'been able in some cases to trace them to the cortex.' He was, however, unable to accept Renault's conclusion that they supplied lateral rootlets.

Since my first observation of these vascular branches I have examined a large number of Stigmarian rootlets from the Cash, Hick, and Wild Collections of the Manchester Museum at the Owens College, with the result that I not only found numerous specimens showing such vascular branches, but was able to trace them to their termination in the cortex, as I mentioned at the end of my earlier paper ('02). From the relatively large number of rootlets, I have chosen four to illustrate the structure, the origin, the course and termination of these vascular strands. Figures I and 2 (Pl. XXVI) are taken from rootlets of a different type from that which $I$ have previously figured ('02), but of the same type as the one represented by Renault ('82). The middle cortex appears in these to be entirely absent, as is the case, indeed, in the majority of

${ }^{1}$ Solms-Laubach ('91), Fig. 35, p. 27.

${ }^{2}$ Slide, No. 109 in the Hick Collection in the Manchester Museum, Owens College. 
Stigmarian rootlets. In the rootlet represented in Fig. $1^{1}$, as in some other rootlets which are cut longitudinally, there can be seen running obliquely between the parenchymatous sheath of the inner cortex $(i . c$.$) , which surrounds the stele, and the$ outer cortex $(o . c$.$) a delicate strand of tracheids (t r$.$) sur-$ rounded by a layer of parenchymatous cells. Though its origin from the central stele is not seen, there can, I think, be no doubt as to the identity of this delicate strand with the vascular branch described by Renault. In confirmation of this view, it may be mentioned that the position of this strand of tracheids is on that side of the rootlet which lies nearest to the protoxylem. Hence it would not be wrong to assume that it was probably connected with the protoxylem elements in the same way as in the rootlet figured by Renault.

Another point of agreement with Renault's figure is the small process $(p$.) passing off from the parenchymatous sheath which would seem to have connected it with other parenchymatous cells of a delicate character, forming lacunar or trabecular tissue, remnants of which can be seen near the upper end of this strand, as also in Renault's figure.

For all these reasons we are I think justified in assuming that the isolated vascular branch seen in Fig. $I$ is similar to that which Renault figures as connected with the protoxylem of the stele, and which in a very different type of rootlet I also found connected with the protoxylem elements.

Both Renault's figure and my previous one were taken from transverse sections, and the fact that in the latter the vascular branch ran only for a short distance transversely into the middle cortex may be taken to indicate that after leaving the stele its course must have been more or less oblique, a supposition which is borne out by the longitudinal section as represented in Fig. I.

But while the inner connexion of these vascular branches with the protoxylem of the central cylinder was established by Renault, very little has been known about their termination. Renault, rather naturally, was inclined to regard them 
as supplying lateral rootlets, but he did not figure the latter, and he stated that owing to the minuteness of these strands, which do not exceed $\frac{1}{10}$ of a millimetre, 'ce n'est donc que dans des cas assez rares que les empreints pourront reproduire les cicatrices laissées par des radicelles.'

Such slender evidence, especially as the Stigmarian rootlets exhibit well-marked dichotomy, justified Williamson's and Solms-Laubach's refusal to accept Renault's conclusions. Dr. Scott, though he has been able to observe these strands, states in his manuscript notes referred to above, with reference to a well-marked strand in one of his preparations (slide, No. I I 3 ), that 'there is no sign of branching.' In one of these rootlets he observed 'an oblique strand of xylem running from the stele to the inner edge of the cortex.' And indeed, as we shall see presently, that is as far as the strand generally goes. In the rootlet represented in Fig. $2^{1}$ the termination of a vascular branch in the outer cortex is reproduced. Here the cortex will be seen to contain a number of curiously wide and short tracheids with delicate spiral or reticulate markings, resembling very closely the spirally-marked cells which form the termination of the finest ramifications of the veins in leaves. A characteristic feature of these cortical tracheids is the wide interval between two successive turns of the spiral thickening.

These cells are seen in Fig. 2 at $(a)$ on the inner side of the outer cortex. At $(c)$ where we obtain a tangential view of this portion of the cortex it will be seen that these cells form a fairly broad patch. At $(b)$ the cells become narrower in diameter and somewhat more closely set, and this is evidently the point at which a connexion existed with the vascular strand of fine and closely-marked tracheids running out from the protoxylem group. This connexion is not observable in this section, but I was fortunately able to discover a longitudinal section in which this connexion was preserved.

Fig. $5^{2}$ is a drawing made from a section in which we have not only the connexion of the spiral tracheids of the cortex

1 Hick Collection, No. I07.

2 Cash Collection, No. 40 I. 
with the vascular strand, but also the continuity of the latter with the stele of the rootlet.

This rootlet is unfortunately somewhat compressed, so that the space between the stele and the outer cortex is very much reduced, and the vascular strand is thrown into a fold. It will be seen that in this rootlet the strand on passing out from the protoxylem elements takes a very oblique direction, and would not in transverse section have had the appearance of the vascular strand figured by Renault. In structure, however, it shows the same features, and is surrounded by a sheath of parenchymatous cells, from which trabecular tissue $(\operatorname{tr} b$.) runs to the parenchyma of the stele. On reaching the outer cortex the vascular branch communicates at first with some closelyset tracheids very similar to those at (b) in Fig. 2, and these are in their turn connected with wider spirally-marked tracheids $(s p . t r$.$) . From a comparison of Figs. 2$ and 5 I have no hesitation in considering $(b)$ in Fig. 2 as the point of entrance of the vascular strand into the outer cortex of that rootlet. Another feature shown by the longitudinal section represented in Fig. 5 is that the vascular strand seems to have been in some cases continued for a considerable distance beyond its entry into the outer cortex, and connected with several groups of spiral tracheids. Indeed, a branch $(v . b r$.) is given off from the vascular strand close to its entry into the outer cortex, and this branch was in all probability connected with another patch of spiral tracheids at some other part of the root. It is difficult to ascertain what was the size and distribution of these patches of spirally-marked cells of the outer cortex. As will be seen from Fig. 2, and as is apparent from other preparations, it was of some breadth. In one longitudinal section, indeed, such cells seem to have extended almost halfway round the root. In other cases, however, as can be seen in Fig. 4, the spiral tracheids extended only a little way on either side of the entrance of the vascular strand. No doubt there was considerable variation in this respect in the different types of rootlets, which belonged probably to different Lepidodendroid plants. 
It will be seen that in the two rootlets in which the spirallymarked elements are described in the cortex they are found in the innermost layers of the cortex, and therefore within the very dark cells which are so often found, forming a more or less continuous ring in the outer cortex. It is hardly possible to say whether the darkness of the cell-walls in this layer, which was no doubt due to the cell-walls and not to the contents, marks them out as an impervious or protective sheath ; or whether the cell-walls, though differing in constitution, and probably also in thickness, may not have been as readily permeable as those of the other cells of the cortex. Even if they were less permeable, or actually impervious, there may have been at intervals thin-walled elements similar to those of a thick-walled endodermis, and through such thinwalled cells the water taken in at the periphery might have reached the spiral tracheids on the inside of the cortex.

In his memoir on Stigmaria, Williamson figures a transverse section of a rootlet ${ }^{1}$ in which there appear, in close proximity to the protoxylem group, two other groups of spirally-marked tracheids in the parenchymatous sheath of the stele. These isolated groups of tracheids, together with the small tracheids immediately adjoining the metaxylem, Williamson considers to 'constitute the monarch point, to which the remaining vessels of the bundle were added centripetally.' A similar condition had been previously figured by Williamson ${ }^{2}$ in Part XI of his Organization of the Fossil Plants of the Coal Measure, and the same explanation given of its occurrence. Dr. Scott, in his manuscript notes, dissents from this interpretation because 'the elements at $\left(f^{\prime \prime \prime}\right)$ are too big and too remote from the protoxylem to form part of it.' He considers that we have here another case of a tracheidal strand being given off from the protoxylem. This conclusion is undoubtedly correct, the difference in appearance between Williamson's figure and that of Renault being due to the fact that the strand of tracheids runs very nearly parallel to the

1 Williamson, W. C. ('87), Pl. XI, Fig. 59.

${ }^{2}$ Id. ('81), Pl. LIII, Fig. I9. 
central cylinder as it does in Fig. 5 of the present communication, and not at right angles as was the case with the rootlet figured by Renault and that figured previously by me ('02). The correctness of Dr. Scott's view is further borne out by several rootlets in the Manchester Museum, one of which is represented in Figs. 3 and $4{ }^{1}$. This rootlet is one of a type not uncommon among Stigmarian rootlets, but differing both from the one first described by me with a vascular branch ('02), and also from the three rootlets described above. It will be seen that in this third type of rootlet the stele does not lie freely in the space left between the inner and outer cortex, but is definitely connected with the latter by a strand of parenchymatous cells, reminding one of the similar connecting strand in the roots of Isoetes. Such rootlets have been figured before, but no special attention has been drawn to this feature, which might from Williamson's Fig. $16^{2}$ be thought to be an attribute of very young roots only. A careful examination of a large number of rootlets of this type, many of them evidently fully developed, convinces me that it is a somewhat different type of rootlet. In the one represented in Fig. 3 it will be seen that this parenchymatous connexion between the stele and the outer cortex is traversed by three strands of tracheids $\left(t r^{\prime}, t r^{\prime \prime}, t r^{\prime \prime \prime}\right)$ similar to those figured by Williamson, and rightly interpreted by Dr. Scott as vascular branches similar to those described by Renault. From the number of these isolated groups of tracheids it would appear that such branches were given off at short intervals in the rootlets of his type, and that they ran very obliquely towards the cortex, so that two or three strands are cut across in transverse section. Their oblique path is evident from the enlarged drawing of a portion of this rootlet (Fig. 4), in which the lateral markings of the tracheids are visible in a transverse section. It is, of course, possible that these strands were not all of independent origin, but that the appearance may be due to some branching of the strand similar to that of Fig. 5

1 Hick Collection, No. 75.

2 Williamson, W. C. ('81), P1. LIII, Fig. I6.

Q q 2 
but of a more complex character, so that more numerous branches appear in the transverse section. Of this, however, I have not been able to see any trace in such longitudinal sections of this type of rootlet as I have been able to examine. Unfortunately they were mostly too oblique to allow any very definite statement to be made. It will be noticed that in Fig. 3, as in the case referred to by Dr. Scott, the tracheids increase somewhat in size soon after they are given off from the protoxylem, a feature which is not noticeable in the other types of rootlets, where the dilated tracheids are only observable after the strand has reached the outer cortex. In all cases, however, we have that sequence of narrower tracheal elements to which Strasburger draws attention ('91)1. He points out that in all cases the narrower absorb water from the wider elements. In both categories of Stigmarian rootlets, therefore, the flow of water would take place from the wider tracheids of the cortex to the narrower protoxylem elements of the central cylinder. The rootlet represented in Figs. 3 and 4 shows very clearly the wider spiral tracheids of the cortex, similar in general features to those of the rootlets in Figs. 2 and 5 . These tracheids appear, however, in the second type of rootlet to be differentiated into narrow ones running longitudinally in the rootlet and wider transverse ones. This arrangement reminds one forcibly of the terminal ramifications of the vascular bundles in a Monocotyledonous leaf as figured by De Bary for Zea Mais ${ }^{2}$.

The position of the spiral tracheids is also different in this last rootlet from that described for the other rootlets. It will be seen in Figs. 3 and 4 that the tracheidal elements of the cortex are here found externally to the cells with dark cell-walls. Whether these were in all cases thick walls, or whether their constitution caused a discolouration of the cellwall substance, it would be difficult to say; but the presence of the tracheids on the outside of this layer of cells would suggest that in this rootlet they might be less permeable

1 Strasburger, E., Leitungsbahnen, p. 873 .

${ }^{2}$ De Bary, A. ('84), Fig. I75, p. 37 I. 
than the lighter external parenchyma. It is a noticeable feature of these rootlets, too, that the thin-walled cells of the outer cortex are considerably larger where they adjoin the tracheidal patch than in any other part of the circumference, and present therefore a specialized appearance, and one suggestive of very active absorption at this point. This larger-celled portion of the outer cortex does not run continuously along the rootlet, but, as can be seen from longitudinal sections, is confined to those regions where a vascular branch terminates in the cortex in wide spiral tracheids.

We are in the case of fossil plants at a great disadvantage in endeavouring to explain the function of unknown organs, as we cannot adduce any experimental evidence, and must base our conclusions on inferences drawn from anatomical facts only. In the present case the specialized cells of the cortex just referred to may be taken to give an important clue to the function of these peculiar vascular strands of the Stigmarian rootlets. It would appear from Figs. 3 and 4 that the rootlets were more particularly active as absorbent organs at those points at which the large-celled parenchyma occurred beneath the epidermis. Not only are these cells marked out as likely to maintain active osmosis, but they were in the most advantageous position to pass on the water they had absorbed to the central cylinder across the parenchymatous bridge which joins the outer cortex at this same point. The passage of water might be considerably accelerated by the presence of the vascular strands described above. As in the leaves, so in the rootlets, there was no direct connexion between the turgid parenchyma and the narrow spiral tracheids, but an intermediate tissue of wide spiral tracheids was interpolated.

In the case of the leaves of Monocotyledons and Dicotyledons, these tracheids, through which the outward diffusion of water takes place, are generally spirally-marked and of a very angular appearance ${ }^{1}$-due, as De Bary states, to the end surfaces bordering on the parenchyma being usually 'cut off sharply either transversely or obliquely.' The same description

${ }^{1}$ Cp. Sachs, J. ('87), Fig. 196. 
might be given of some of the tracheids in the outer cortex of the Stigmarian rootlet. Comparison might also be made with those plants which possess a more definite and restricted 'transfusion tissue,' as defined by Mohl ('71). De Bary ('87) describes this transfusion tissue in the Conifers as 'attached to the xylem by means of one or two longitudinal rows of tracheids,' and as consisting of tracheids which 'are on the average shorter and wider, and have terminal surfaces which are but little oblique, and may even be horizontal.' This, too, would very fitly describe the tracheidal elements seen in Figs. 2 and 5 of the present paper. This comparison with the 'transfusion tissue,' in the restricted sense, receives additional weight from the fact that the leaves of the Lepidodendraceae possessed a considerable amount of transfusion tissue ${ }^{1}$, the cells of which resemble very closely the spiral tracheids in the rootlets of Stigmaria. A clear functional difference must, of course, have existed between these two very similarly constituted cells of the root and leaf of the Lepidodendraceae. The latter must have facilitated the outward passage of water in the leaf, whereas the former, if my interpretation is correct, must have accelerated the inward passage of water in the root.

This would not be the only instance of similarly constituted organs acting in opposite ways in different parts of a plant. Indeed, the same organ may act both as a water-secreting or absorbing structure, as has been shown by Haberlandt ('95) and Von Minden ('99) in the case of the hydathodes of many leaves. The 'digestive glands' of insectivorous plants may be taken as a special instance of the double function of modified hydathodes.

A further support for the view I have advanced as to the probable function of the tracheidal patches of the outer cortex is gained from an interesting instance to which Professor F.W. Oliver has drawn my attention. Jönsson ('02), in his account of the germination of $A_{g} a v e^{2}$, refers to the occurrence in the

1 Cf. Scott, D. H. ('00), Studies in Fossil Botany, p. 148.

${ }^{2}$ Cp. Jönsson, B. ('02), Pl. III, Fig. Io. 
top of the cotyledon, which forms the absorbing organ of the seedling, of a considerable development of fibrous cells. These spirally-marked cells are 'short and parenchymatous,' and remind him of the tracheids found under the epidermis of the glands of Drosera. In the latter the tracheids are no doubt to a great extent excretory as well as absorptive, but in this 'Saugorgan' of Agave the function of these tracheids must be exclusively absorptive, and they would therefore readily compare with the cortical tracheids in the Stigmarian rootlet.

The only roots which offer any counterpart to the vascular strands with tracheidal terminations in Stigmarian rootlets are the highly modified roots of certain parasitic Phanerogams. Here, as Solms ('68) has shown, the haustoria are often traversed by vascular strands quite similar in structure to the ends of bundles in the foliar expansions. We have, therefore, here an instance of roots becoming modified for special reasons very much in the same way as the Stigmarian rootlets were adapted to their peculiar conditions.

That the roots of Stigmaria should require some special provision for facilitating the absorption of water might be expected from a consideration of their general structure. In some cases, as in the rootlet reproduced in Fig. 3, a thin band of parenchyma was the only connexion between the stele and the outer cortex, and through it alone could a passage of water take place from the peripheral to the central portion of the rootlet. In other cases there appears to have been only a delicate trabecular tissue constituting the middle cortex, and in some there was possibly no definite connexion between the stele and the outer cortex, except by such vascular strands as are described above. In all cases there seems sufficient reason for the existence of special vascular communication between the central cylinder and the peripheral tissues to ensure an adequate supply of water.

It should be remembered that in the roots of Calamites, which probably existed in similar conditions of climate and habitat, the roots were not monarch, and had numerous stout rays of parenchymatous cells running from the epidermal 
tissue to the various protoxylem groups. The same may be said of most recent aquatics. The only existing type of aquatic with a monarch root, Isoetes, has as a submerged plant a much smaller requirement for root-absorption, and is apparently able to dispense with this additional method of conduction shown to be characteristic of the various types of Stigmarian rootlets.

\section{General Conclusions.}

In the various types of Stigmarian rootlets fine strands of spiral tracheids, like those described by Renault, may be seen leaving the protoxylem elements.

These strands do not pass out to lateral rootlets as suggested by Renault, but terminate in the outer cortex, sometimes in connexion with distinct groups of large parenchymatous cells.

The vascular strands are not directly connected with the parenchyma of the outer cortex, but pass out into short and wide spirally-marked cells resembling the transfusion cells of leaves.

The vascular strand and the transfusion cells in which it terminates form a special means of conducting water from the peripheral to the central tissues of the rootlet, a means which is rendered necessary by the development of the middle cortex into an air-conducting tissue or space.

The existence in the cortex of Stigmarian rootlets of spiral tracheids comparable with the transfusion-cells of Lepidodendroid leaves may possibly be taken by some palaeobotanists as a further argument in favour of Schimper's view of the homology of these two sets of organs ${ }^{1}$.

In making the above comparison, however, I desired merely to refer to them as organs of similar structure and analogous to some extent even in function, in so far as they establish a passage between the parenchymatous and vascular tissues. I have searched in vain in Lepidodendroid leaves for the fine vascular strand which traverses the middle cortex of the

1 Schimper, W. Ph., Paléontologie végétale, I872, vol. ii, p. II I. 
rootlet, and I regard both this conducting strand and the tracheids of the outer cortex as a highly specialized adaptation of the rootlet, and not as the survival or transformation of transfusion-cells of a leaf-like organ. Except in their position, the rootlets and leaves of the Lepidodendraceae seem to be as different from one another and quite as highly specialized as those of Isoetes. In this latter plant, too, the rootlets have a fairly regular arrangement on the basal part of the stem, which may readily be compared with the dilated base of Pleuromeia. It is quite possible also to conceive the latter to be morphologically equivalent to the 'rhizome' or 'rhizophore' of Stigmaria, and possibly of both, as a special development of the protocorm of the ancestral sporophyte. Such a protocorm would not have borne any leaves at its base, but its rootlets may have had the same position as the leaves on the stem. 


\section{BIBLIOGRAPHY.}

De BAry, A. ('84): Comparative Anatomy of Vegetative Organs of Phanerogams and Ferns. (Engl. Transl.), I 884 .

HABERLANDT ('95): Anatomisch-physiologische Untersuchungen über das tropische Laubblatt. Sitzungsberichte der Kais. Acad. d. Wiss. Wien, 1895 .

Jönsson, B. ('02): Die ersten Entwicklungsstadien der Keimpflanze bei den Succulenten. Lund Universitets Årsskrift, Bd. xxxviii, 1902 .

Von Minden, M. ('99) : Beiträge zur anatomischen und physiologischen Kenntniss wassersecernirender Organe. Bibliotheca Botanica, Heft 46, I 899.

MoHL, H. von ('71): Morphologische Betrachtung der Blätter von Sciadopitys. Botanische Zeitung, $187 \mathrm{I}$.

Renault, M. B. ('81) : Cours de Botanique Fossile. Paris, I88I. I882.

(82): Étude sur les Stigmaria. Annales des Sciences géologiques,

SAchs, J. ('87) : Lectures on the Physiology of Plants. (Engl. Transl.). Oxford, I 887 .

Schimper, W. Ph. ('72): Paléontologie végétale, Vol. II.
Scott, D. H. ('00): Studies in Fossil Botany, I900.

Solms-Laubach, Count zU ('68): Ernährungsorgane parasitischer Phanerogamen. Pringsheim's Jahrbücher, vol. vi, I 868.

('91) : Fossil Botany. Engl. Transl., I89I.

Strasburger, E. ('91): Ueber den Bau und die Verrichtungen der Leitungsbahnen in den Pflanzen. Histologische Beiträge, iii, I891.

Weiss, F. E. ('02) : On Xenophyton radiculosum, and on a Stigmarian rootlet probably related to Lepidophloios fuliginosus. Memoirs and Proceedings of the Manchester Literary and Philosophical Society, 1902.

Williamson, W. C. ('81) : On the Organization of the Fossil Plants of the Coal Measures. Pt. XI. Phil. Trans., I88I.

('87): A Monograph on the Morphology and Histology of Stigmaria ficoides. Palaeontographical Society, I887. 


\title{
EXPLANATION OF PLATE XXVI.
}

\author{
Illustrating Professor Weiss's paper on Stigmarian Rootlets.
}

Figs. I, 2, and 3, from photographs taken by Mr. Abraham Flatters.

Fig. I. Photograph of a rootlet cut in longitudinal direction from slide, No. 10\% of the 'Hick Collection' in the Manchester Museum. $\times 60 . \quad$ i.c. $=$ inner cortex ; o.c. $=$ outer cortex $; p$. $=$ process from parenchymatous sheath indicating the trabecular nature of middle cortex $; t r .=$ tracheids of vascular branch.

Fig. 2. Photograph of another rootlet from slide, No. Io7 in the 'Hick Collection.' $\times 60$. This section is cut rather obliquely so that the right-hand portion passes tangentially through the outer cortex. The central cylinder is not seen in this section. $0 . c_{.}=$outer cortex; sp.tr. $=$spiral tracheids of the outer cortex.

Fig. 3. Photograph of a rootlet from slide, No. 75 in the Hick Collection. $\times 3^{\circ}$. This rootlet shows the stele connected with the outer cortex by a definite strand of parenchymatous tissue. In this parenchymatous strand will be seen traces of spiral tracheids cut slightly obliquely.

Fig. 4. A more enlarged drawing of a portion of Fig. 3 showing, i.c.=inner cortical sheath ; $p x .=$ protoxylem ; $t r^{\prime}, t r^{\prime \prime}, t r^{\prime \prime \prime}=$ three portions of vascular strands running to outer cortex ; $s p . t r_{0}=$ spiral tracheids of outer cortex ; par. $=$ patch of large-celled parenchyma of outer cortex.

Fig. 5. Enlarged drawing of a portion of a longitudinal section of a rootlet from slide, No. 40I in the 'Cash Collection' of the Manchester Museum. In this rootlet the vascular strand is seen in connexion both with the protoxylem of the central cylinder, and also with the spiral tracheids of the outer cortex. Owing to compression of rootlet the vascular branch is thrown into a fold; st. $=$ stele with inner cortical sheath $i_{. c .}$; tr.b.=trabecular tissue connecting the vascular strand; $v . b r .=$ branch from original vascular branch; $s t_{0}=$ outer cortex with spiral tracheids sp.tr. 


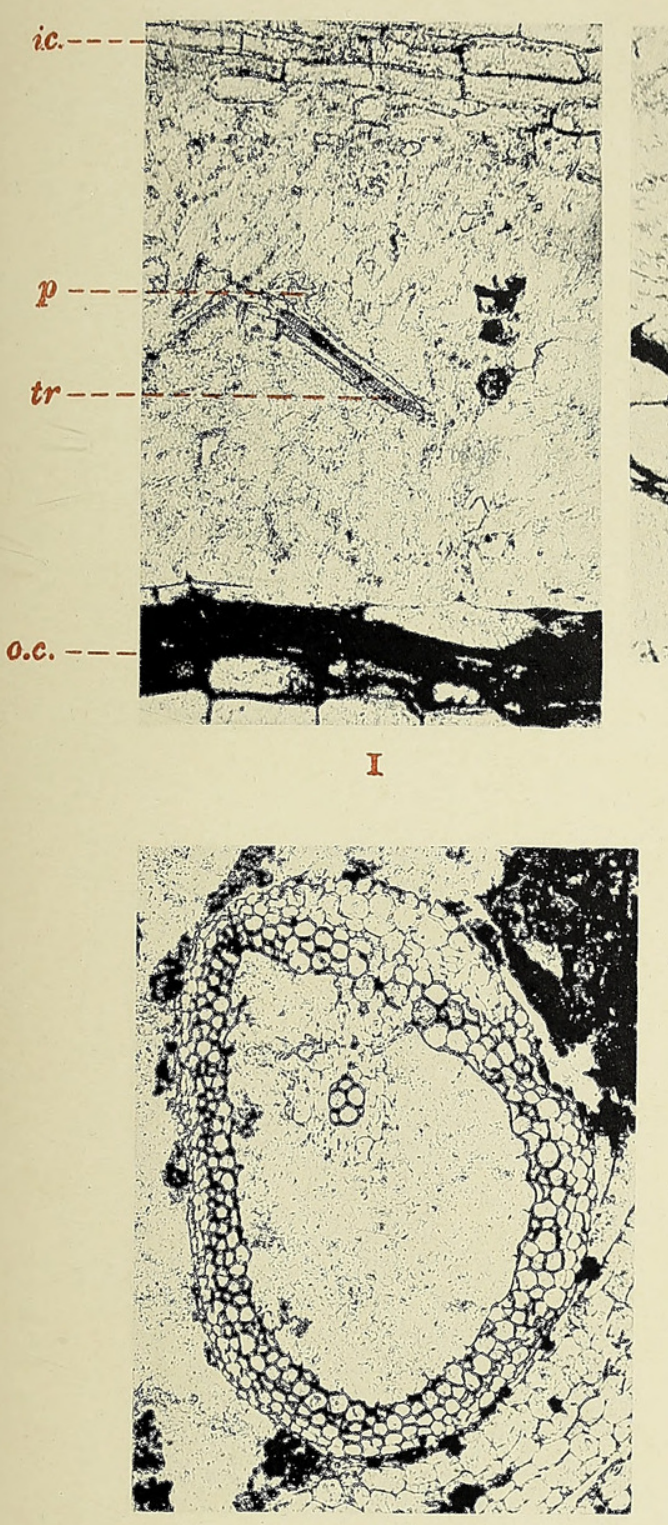

3
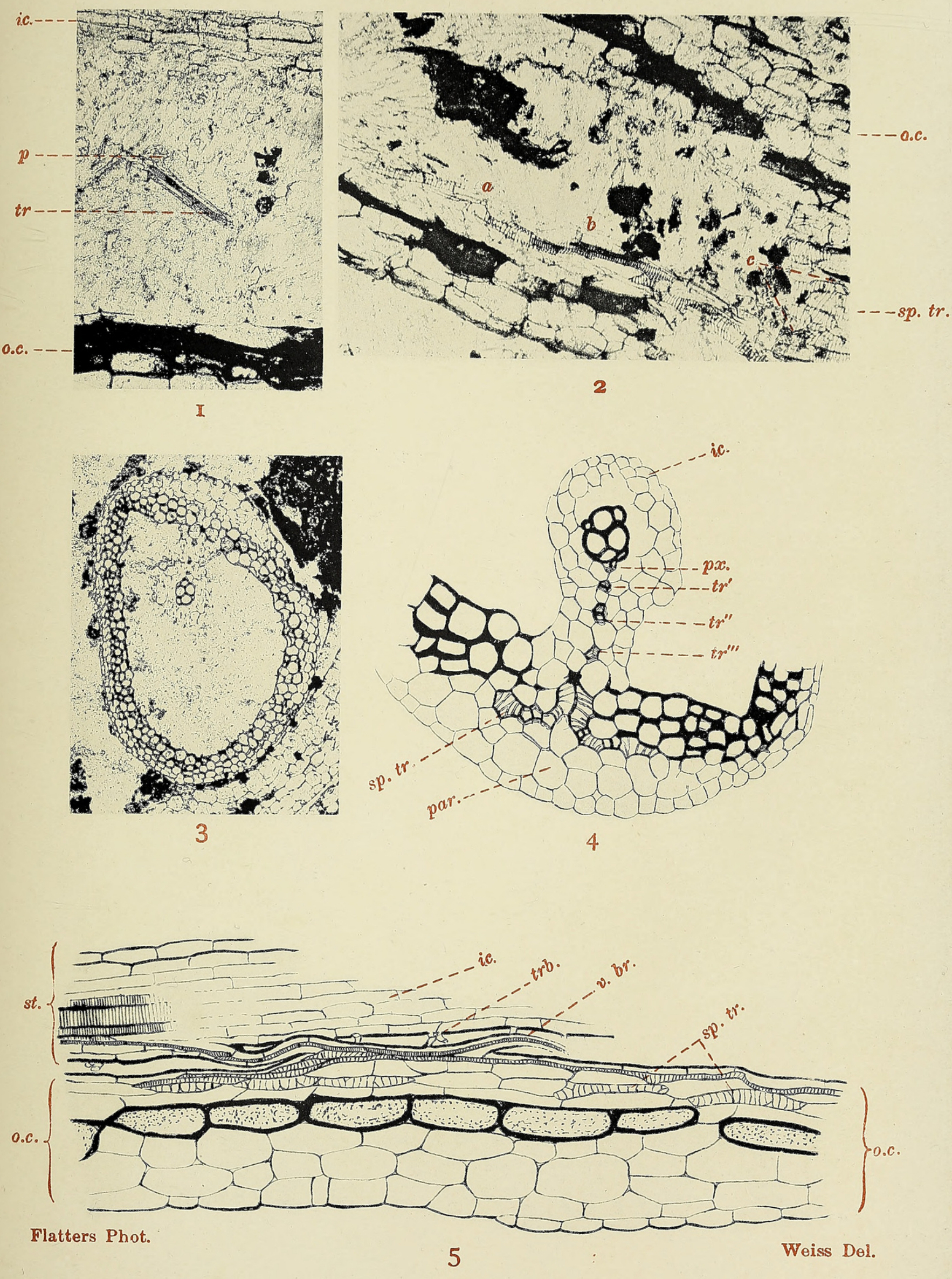


\section{$2 \mathrm{BHL}$ Biodiversity Heritage Library}

Weiss, F. E. 1902. "The vascular branches of Stigmarian rootlets." Annals of botany 16, 559-573. https://doi.org/10.1093/oxfordjournals.aob.a088889.

View This Item Online: https://www.biodiversitylibrary.org/item/233980

DOI: https://doi.org/10.1093/oxfordjournals.aob.a088889

Permalink: https://www.biodiversitylibrary.org/partpdf/318690

\section{Holding Institution}

Smithsonian Libraries

\section{Sponsored by}

Biodiversity Heritage Library

\section{Copyright \& Reuse}

Copyright Status: Not in copyright. The BHL knows of no copyright restrictions on this item.

This document was created from content at the Biodiversity Heritage Library, the world's largest open access digital library for biodiversity literature and archives. Visit BHL at https://www.biodiversitylibrary.org. 